Primljen / Received: 21.1.2016. Ispravljen / Corrected: 4.11.2016.

Prihvaćen / Accepted: 20.1.2017. Dostupno online / Available online: 10.2.2017.

\title{
Application of cone penetration test (CPT) results for soil classification
}

Authors:

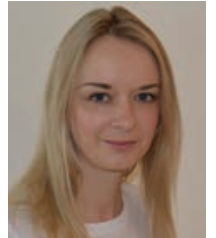

Lovorka Librić, PhD. CE

University of Zagreb

Faculty of Civil Engineering

Departement of Geotechnical Engineering llibric@grad.hr

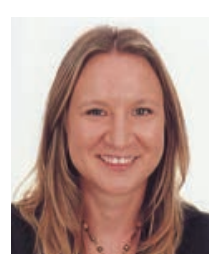

Assist.Prof. Danijela Jurić-Kaćunič, PhD. CE University of Zagreb

Faculty of Civil Engineering

Departement of Geotechnical Engineering djk@grad.hr

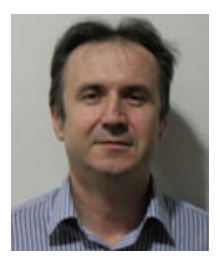

Prof. Meho Saša Kovačević, PhD. CE University of Zagreb

Faculty of Civil Engineering

Departement of Geotechnical Engineering msk@grad.hr

\section{Lovorka Librić, Danijela Jurić-Kaćunić, Meho Saša Kovačević}

Preliminary note

\section{Application of cone penetration test (CPT) results for soil classification}

The paper presents an application of CPT results for soil classification according to Unified Soil Classification System (USCS) and European Soil Classification System (ESCS) by using computer program KLASIF. The correlations between the CPT results and the parameters for soil classifications are shown. The relatively good success in soil classification using CPT results on the example of irrigation canal in Bid bosut field is presented.

\section{Key words:}

oil classification, CPT, correlation, standard, USCS, ESCS

Prethodno priopćenje

Lovorka Librić, Danijela Jurić-Kaćunić, Meho Saša Kovačević

Primjena rezultata statičkog penetracijskog pokusa za klasifikaciju tla

U radu je prikazana primjena rezultata CPT pokusa za klasifikaciju tla prema Jedinstvenoj klasifikaciji tla (USCS) i Europskoj klasifikaciji tla (ESCS) korištenjem računalnog programa KLASIF. Prikazane su korelacije između rezultata CPT pokusa i parametara za klasifikaciju tla. Na primjeru kanala za navodnjavanje Biđ-Bosutskog polja pokazano je relativno uspješno klasificiranje tla pomoću CPT pokusa.

Ključne riječi:

klasifikacija tla, CPT, korelacija, norma, USCS, ESCS

Vorherige Mitteilung

Lovorka Librić, Danijela Jurić-Kaćunić, Meho Saša Kovačević

\section{Anwendung von Resultaten des statischen Penetrationsversuches zur Bodenklassifizierung}

In dieser Arbeit wird die Anwendung von Resultaten des CPT Versuchs zur Bodenklassifizierung gemäß einheitlicher Bodenklassifizierung (USCS) und Europäischer Bodenklassifizierung (ESCS) mittels des Computerprogramms KLASIF dargestellt. Korrelationen zwischen Resultaten des CPT Versuchs und Parametern der Bodenklassifizierung werden erläutert. Am Beispiel des Bewässerungskanals des Feldes von Bid-Bosut wurde eine relativ erfolgreiche Bodenklassifizierung basierend auf CPT Versuchen aufgezeigt.

Schlüsselwörter:

Bodenklassifizierung „CPT, Korrelation, Normen, USCS, ESCS 


\section{Introduction}

The soil classification, i.e. division into categories and subcategories with pertaining symbols, enables understanding of mechanical behaviour of soil under the influence of load. Traditionally, soils were divided according to grain size into noncoherent or coarse-grained soils (gravel and sand), and coherent or fine-grained soils (silt and clay). Non-coherent soils are then categorized based on their relative proportion in the total mass of the soil tested, while coherent soils are categorized according to their plasticity properties. The procedure for describing and labelling of soils is called soil classification.

The world's most widely known and used soil classification is the Unified Soil Classification System (USCS), created through modification of the Airfield Classification System (ACS) [1, 2]. Classifications according to the British Soil classification System (BSCS) [3-5] and the Deutsches Institut für Normung (DIN) are widely used in Europe [6]. Kovacevic and Juric-Kacunic [7] developed the European Soil Classification System (ESCS) for engineering purposes, which makes use of the soil description and symbols in line with the European standard EN ISO 14688$1[8,9]$. The system is based on soil classification principles prescribed in EN ISO 14688-2 [10, 11].

In order to ensure compliance with the European guidelines for soil description and classification, Kovačević et al. [12] placed emphasis on the need to develop information support for the implementation of ESCS and USCS in order to facilitate their parallel use, i.e. on the need to transfer to and adopt the soil classification that is in line with European guidelines.

\section{Information support for implementation of USCS and ESCS}

cal Engineering, Faculty of Civil Engineering in Zagreb. The program provides IT support for implementing the USCS and ESCS classifications and facilitates their parallel use (Figure 1).

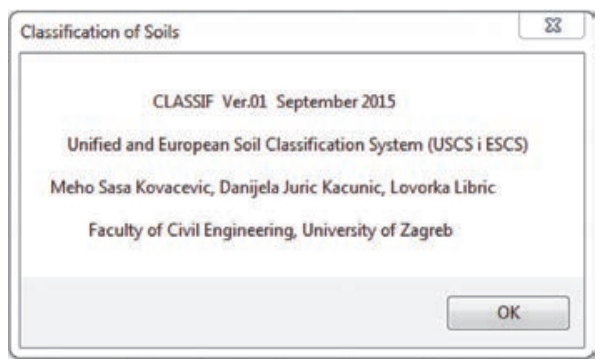

Figure 1. Initial user interface in CLASSIF

The CLASSIF was developed using Microsoft Excel and the Visual Basic for Applications (VBA) integrated programming languages, which enabled programming of special functions that are not included in Microsoft Excel. The program is available for download from the following link: http://www.grad.unizg.hr/ zavod_za_geotehniku.
Input data for both classifications are the same, which enables simple comparison of results. The total number of input parameters that can be set or changed is eight (Figure 2). After changing any of the input variables, new classification results are obtained, which is in line with the way Microsoft Excel works, although final results of the classification do not necessarily change with each change of the variables. For example, changing the liquid limit will not affect the result of the two soil classifications if the percentage of fine particles is below $5 \%$.

The results of soil classification using the CLASSIF for USCS and ESCS classifications are shown in Figure 3.

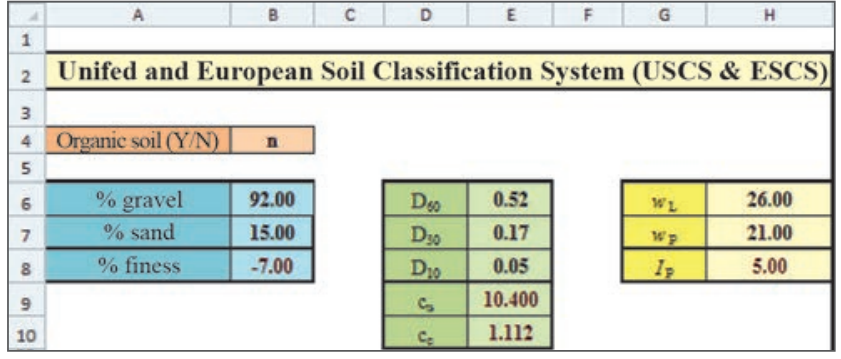

Figure 2. Entering of input variables into CLASSIF

Unifed and European Soil Classification System (USCS \& ESCS)

\begin{tabular}{|c|c|c|c|c|c|}
\hline Organic soil $(\mathrm{Y} / \mathrm{N})$ & $\mathrm{n}$ & & & \multirow[b]{2}{*}{$w_{L}$} & \multirow[b]{2}{*}{44.12} \\
\hline$\%$ gravel & 0.00 & $\mathrm{D}_{60}$ & 0.52 & & \\
\hline$\%$ sand & 32.78 & $\mathrm{D}_{30}$ & 0.17 & $w_{P}$ & 25.44 \\
\hline \multirow[t]{3}{*}{$\%$ fines } & 67.22 & $\mathrm{D}_{10}$ & 0.05 & $I_{\mathrm{P}}$ & 18.68 \\
\hline & & $c_{u}$ & 10.400 & & \\
\hline & & $\mathrm{c}_{\mathrm{c}}$ & 1.112 & & \\
\hline \multicolumn{6}{|c|}{\begin{tabular}{|l} 
Jedinstvena klasifikacija tla \\
Unified Soil Classification System (USCS)
\end{tabular}} \\
\hline $\begin{array}{l}\text { Fine-graind soil (more } \\
\text { Liquid limit less than } \\
\text { Lean clay } \\
\text { Percent of coarse gre: } \\
\text { Percent of gravel less }\end{array}$ & $\begin{array}{l}\text { an or equ } \\
\text { than or } \\
\text { in } 15 \% d\end{array}$ & W sand & $\begin{array}{l}\text { \%gravel) } \\
\text { group name }\end{array}$ & & \\
\hline \multicolumn{4}{|l|}{ Group name } & & Symbol \\
\hline \multicolumn{4}{|l|}{ Sandy lean clay } & & CL \\
\hline \multicolumn{6}{|c|}{\begin{tabular}{|l} 
Europska klasifikacija tla \\
European Soil Classification System (ESCS)
\end{tabular}} \\
\hline $\begin{array}{l}\text { Fine-graind soil (mor } \\
\text { Liquid between } 30 \% \text { a } \\
\text { Clay } \\
\text { Percent of coarse grea } \\
\% \text { sand }>=\% \text { gravel }\end{array}$ & $\begin{array}{l}\text { an or equ } \\
50 \% \\
\text { than or }\end{array}$ & & & & \\
\hline \multicolumn{4}{|l|}{ Group name } & & Symbol \\
\hline \multicolumn{4}{|c|}{ Sandy intermediate plasticity clay } & & with CII \\
\hline \multicolumn{6}{|l|}{ References } \\
\hline \multicolumn{6}{|c|}{$\begin{array}{l}\text { ASTM D 2487-11: Standard Practice for Classification of Solis for Engineering Purposes (Unified } \\
\text { Soli Classification System) ASTM International, West Conshohocken, PA, 20144. } \\
\text { HRN EN ISO 14688-2:2008 en: Geotechnical - Identifikacija i kalsifik investigation and testing - } \\
\text { Identification and classification of soil - Part 2: Principles for a classification. CEN, } 2008 \text {. } \\
\text { Kovacevič. M.S. Juric-Kacunic, D.: Europiean soil classification system for engineering purposes, } \\
\text { GRADEVINAR } 66 \text { (2014) 9, pp. 801-810, doi: 10.14256/JCE.1077.2014. }\end{array}$} \\
\hline
\end{tabular}

Figure 3. Soil classification using the CLASSIF program 


\section{Cone penetration test (CPT)}

The basic principle of the CPT consists in pushing a specially designed probe into the ground at a controlled rate, with constant measurement of tip resistance at the tip of the probe and friction at the probe sleeve, activated upon pushing of the probe between the sleeve and the surrounding ground. In addition to determining the tip resistance and sleeve friction, it is also possible to measure pore pressure and temperature in the zone around the probe, collect data on seismic wave velocities, etc. CPT is widely applied in different types of soil. Its advantages are: fast and continuous measurements, repeatability and reliability of measuring, feasibility and productivity, and the fact that it is a strong theoretical basis for interpretation. Its main disadvantages are: pushing can be of limited use in gravels and cemented soils, handling can be done by skilful individuals only, no soil samples are taken, and high initial investments into equipment and personnel training are needed.

The following basic parameters are continuously measured during the pushing of the CPT probe: cone tip resistance $\left(q_{\mathrm{c}}\right)$, sleeve friction $\left(f_{s}\right)$, and pore pressure $\left(u_{2}\right)$. Tip resistance $\left(q_{c}\right)$ represents the stress obtained as the ratio of the total axial load on the tip to the area of the cross-section of the tip (base). Sleeve friction $(f)$ represents the stress obtained as the ratio of the total friction force of the probe and the soil, occurring at the joint of the probe sleeve, to the measured area of the sleeve. Pore pressure $\left(u_{2}\right)$ represents the sum of the in situ pore pressure $u_{0}$ and the increase in pore pressure $\Delta u$ due to the pushing of the cone into the ground. Additional resistance at the tip is generated by the pressure gauge built into the probe and, for this reason, the corrected tip resistance $q_{\mathrm{t}}=q_{\mathrm{c}}+u_{2}(1-a)$ is used as the measured value, where $a$ is the net tip area coefficient obtained through laboratory calibration $(0.70-0.85)$. The friction ratio $\left(R_{\mathrm{f}}\right)$, defined as the ratio of sleeve friction to tip resistance at the observed depth, is often used for the interpretation of CPT results.

During years of research based on numerical simulation of the relevant process and comparison of results with other field and laboratory results, procedures based on the three values measured during the pushing of the probe into the ground $\left(q_{t^{\prime}} f_{\mathrm{s}}\right.$ and $\left.u_{2}\right)$ have been established for classification, i.e. for determining the soil profile, mechanical characteristics of soil, parameters of soil flow and consolidation, and indication of soil sensitivity to liquefaction [13].

\section{Charts for soil classification using the CPT}

Scientists have been studying soil classification charts based on CPT for the past five decades. The first research in this area was presented by Begemann in 1965 [14]. He proved that, in general, coarse-grained soils have a higher tip resistance $q_{c}$ and sleeve friction $f_{s}$ compared to fine-grained soils, and that it is impossible to classify soils based solely on tip resistance or sleeve friction, but rather on their combination. He proved that soil type is a function of the relationship between the sleeve friction and tip resistance, expressed as friction ratio $R_{\mathrm{f}}$. He created a chart showing the dependence between sleeve friction and tip resistance (Figure 4) in which friction coefficients are represented by line inclinations designating specific soil types. Begemann's chart was created based on an experiment conducted using a mechanical tip in the soils of the Netherlands, and is closely dependent on the geological conditions based on which it was developed. For this reason, it is not widely applied today given that, for example, friction ratio in sand is usually below $1 \%$, whereas the lowest inclination in his chart amounts to $1.2 \%$.

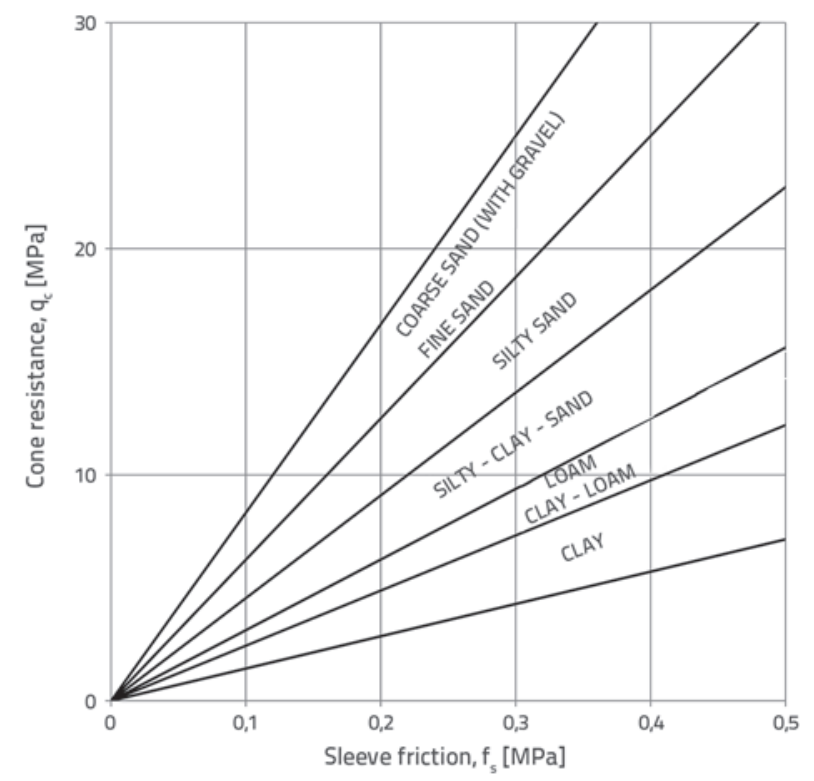

Figure 4. Soil classification chart according to Begemann [14]

In 1974, Sanglerat at al. proposed a chart showing the dependence between the friction ratio and tip resistance, and thus confirmed the assumption that soil type is a function of the friction ratio as the independent variable, and the tip resistance as the dependent variable [15]. In 1978, Schmertmann pointed inter alia to the fact that pore pressure applied to the CPT probe can significantly affect the choice of soil type in line with the charts available at that time [16]. Douglas and Olsen were the first to suggest a soil classification chart using an electric penetrometer, and they linked that chart to the USCS in 1981 [17]. Pore pressure and stress were included in the soil classification chart in 1982 by Jones and Rust [18]. Robertson et al. introduced in 1986 a correction of tip resistance for the value of the measured pore pressure [19]. They also proposed a classification chart in which the soil type is dependent on the pore pressure coefficient and corrected tip resistance. In 1990, Robertson noticed that previous charts had been created based on CPT results for depths of up to $30 \mathrm{~m}$, which is why classification results differed significantly for the same soil type at greater depths. He proposed introduction of normalised values for tip resistance and friction ratio compared to the value of normal vertical total and effective stress in the ground [20]. In 2009, Robertson improved the proposed chart by introducing normalised values of effective vertical stress [21]. In 2016, Mayne adapted Robertson's chart by defining soil type boundaries according to values of the soil behaviour type index I (Figure 5) [22]. 


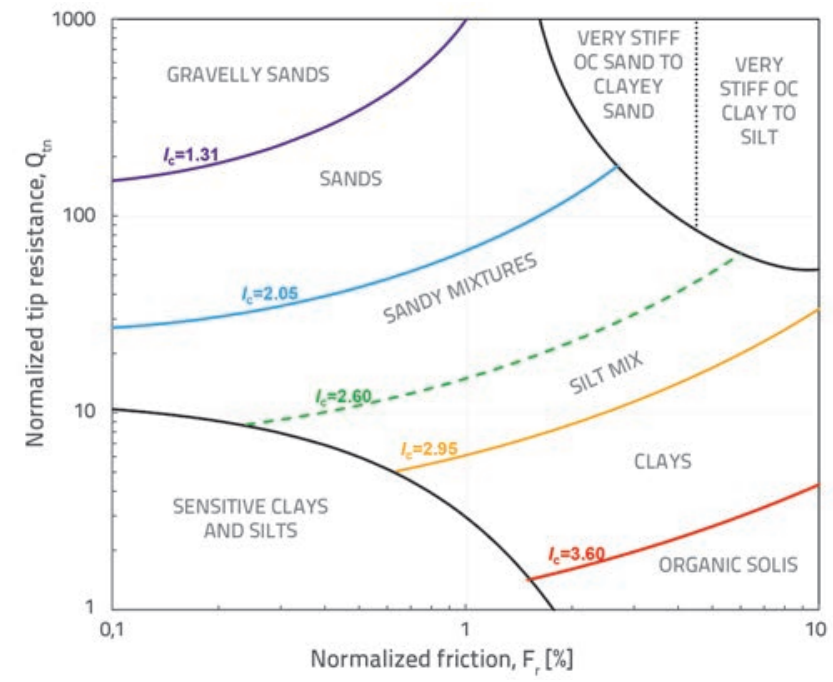

Figure 5. Soil classification chart according to Mayne [22]

\section{Correlations between soil classification parameters and CPT results}

Four groups of parameters are used in soil classification. The first group consists of one parameter - information on whether the soil sample being tested contains organic matter. Such samples are of a darker colour and have an unpleasant odour.

The second group consists of three parameters, i.e. the percentages of gravel, sand and fine particles in the total soil mass. They are obtained through the experiment for determining the particle size distribution of soil according to the US, i.e. European, standards, depending on whether the USCS or the ESCS classification is being conducted $[23,24]$. Given that this soil classification is carried out on soil samples that have passed through a sieve and do not contain particles whose diameter is larger than the largest grain of gravel, the sum of the percentages of gravel, sand and fine particles should equal 100.

The third group consists of two parameters that characterise the grain size distribution curve of soil. These parameters are the coefficient of uniformity $c_{\mathrm{u}}=D_{60} / D_{10}$ and the coefficient of curvature $c_{\mathrm{c}}=D_{30}{ }^{2} /\left(D_{60} \cdot D_{10}\right) . D_{10^{\prime}} D_{30}$ and $D_{60}$ are obtained from the results obtained by determining the particle size distribution of soil, and they represent characteristic grain diameters, of which 10\%, $30 \%$ and $60 \%$ of the sample mass contain grains of smaller diameter. The fourth group consists of two parameters that characterise plastic properties of the soil. These are liquid limit $w_{L}$ and plasticity index $I_{\mathrm{p}}=w_{L}-w_{\mathrm{p}}$. Liquid limit $w_{L}$ and plasticity limit $w_{\mathrm{p}}$ are obtained through experiments for determining Atterberg's limits in line with the US or European standards, depending on whether the USCS or the ESCS soil classification is used $[25,26]$.

\subsection{Organic content}

All previous research has shown that organic soils have an extremely high sleeve friction ratio and an extremely low tip resistance $[14,16,20,27,28]$. According to Robertson [20], a soil contains organic matter if the soil behaviour type index $\left.\right|_{c}>3.60$ :

$I_{\mathrm{c}}=\sqrt{\left(3,47-\log Q_{\mathrm{tn}}\right)^{2}+\left(\log F_{\mathrm{r}}+1,22\right)^{2}}>3,60$

where $Q_{\mathrm{tn}}$ and $F_{\mathrm{r}}$ are the normalised tip resistance and the normalised friction coefficient, respectively, calculated using the following formula:

$Q_{\mathrm{tn}}=\frac{q_{\mathrm{t}}-\sigma_{\mathrm{vo}}}{p_{\mathrm{a}}} \cdot\left(\frac{p_{\mathrm{a}}}{\sigma_{\mathrm{vo}}^{\prime}}\right)^{n}$

$F_{\mathrm{r}}=\frac{f_{\mathrm{s}}}{q_{\mathrm{t}}-\sigma_{\mathrm{vo}}} \cdot 100 \%$

where:

$\sigma_{\text {vo }}$ - total vertical stress in the ground

$\sigma_{\text {vo }}^{\prime}$ - effective vertical stress in the ground

$p_{\mathrm{a}}$ - atmospheric pressure (100 kPa)

$n$ - stress exponent dependent on soil type and stress level, with possible values between 0 and 1 and calculated using the following formula:

$n=0,381 \cdot I_{\mathrm{c}}+0,05 \cdot\left(\frac{\sigma_{\mathrm{vo}}^{\prime}}{p_{\mathrm{a}}}\right)-0,15$

If formula (4) is combined with formulas (1) and (2) for calculating the stress exponent $n$, then we get:

$n=0,381 \cdot\left(\sqrt{\left(3,47-\log \left(\frac{q_{\mathrm{t}}-\sigma_{\mathrm{vo}}}{p_{\mathrm{a}}} \cdot\left(\frac{p_{\mathrm{a}}}{\sigma_{\mathrm{vo}}^{\prime}}\right)^{n}\right)\right)^{2}+\left(\log F_{\mathrm{r}}+1,22\right)^{2}}\right)+0,05 \cdot\left(\frac{\sigma_{\mathrm{vo}}^{\prime}}{p_{\mathrm{a}}}\right)-0,15$

Given that the stress exponent $n$ in formula (5) is located on both left and right sides of the equation, the iterative procedure must be used for its calculation. For the first iteration, on the right hand side $n=1.0$, and the new $n$ value is calculated. This procedure is repeated until the difference in the values of the exponent $\Delta n$ in two subsequent iterations is below or equal to 0.01 .

In addition to the ground water level, the soil bulk density must also be defined in order to determine the total and effective vertical stress in the ground. According to Mayne [22], soil bulk density $\gamma\left(\mathrm{kN} / \mathrm{m}^{3}\right)$ can be calculated using the sleeve friction $f_{\mathrm{s}}$ $(\mathrm{kPa})$ according to the formula:

$$
\gamma=26-\frac{14}{1+\left(0,5 \cdot \log \left(f_{s}+1\right)\right)^{2}}
$$

\subsection{Percentage of fine particles}

The first step in conducting soil classification is the division into fine-grained and coarse-grained soils. According to USCS and ESCS, a soil is classified as fine-grained if $50 \%$ or more of the total quantity of a dry sample passes through a $0.075 \mathrm{~mm}$ sieve (sieve no. 200), that is $0.063 \mathrm{~mm}$ [7].

The percentage of fine particles in the soil increases with an increase in the sleeve friction coefficient, whereas the tip 
resistance decreases [29-33]. According to Robertson and Wride [29], the percentage of fine particles $(F C)$ can be calculated by using the soil behaviour type index $I_{\mathrm{c}}$ according to the formulas:

for $I_{c}<1,26 ; F C=0[\%]$

for $1,26 \leq I_{c}<3,50 ; F C=1,75 \cdot I_{c}^{3,25}[\%]$

for $I_{c}>3,50 ; F C=100[\%]$

for $1,64 \leq I_{c}<2,36$ and $F_{r}<0,5[\%] ; F C=5[\%]$

\subsection{Uniformity and curvature coefficients}

According to USCS, coarse-grained soil can be either well graded or poorly graded, depending on the uniformity coefficient cu and the curvature coefficient $c_{c^{\prime}}$ However, according to ESCS, coarse-grained soil can be well graded, medium graded, or poorly graded [7].

The uniformity coefficient $c_{u}$ increases and curvature coefficient $c_{c}$ decreases with an increase in the friction angle $\varphi$ [34-36]. According to Roy and Dass [34], uniformity and curvature coefficients can be calculated using the friction angle according to the following formulas:

$c_{u}=0,794 \cdot \varphi-19,548$

$c_{u}=-0,083 \cdot \varphi+3,127$

The friction angle $\varphi$ increases with an increase in tip resistance [37-39]. According to Kulhawy and Mayne [37], the friction angle can be calculated using the tip resistance according to the following formula:

$\phi=17,6+11,0 \cdot \log \left(\frac{q_{\mathrm{t}}}{\sqrt{p_{\mathrm{a}} \cdot \sigma_{\mathrm{vo}}^{\prime}}}\right)$

By combining formula (10) with formula (8), we get the formula for calculating the uniformity coefficient by applying the cone penetration test results:

$c_{\mathrm{u}}=-5,574+8,734 \cdot \log \left(\frac{q_{\mathrm{t}}}{\sqrt{p_{\mathrm{a}} \cdot \sigma_{\mathrm{vo}}^{\prime}}}\right)$

By combining formula (10) with formula (9), we get the formula for calculating the curvature coefficient by applying the cone penetration test results:

$c_{\mathrm{c}}=1,666-0,913 \cdot \log \left(\frac{q_{\mathrm{t}}}{\sqrt{p_{\mathrm{a}} \cdot \sigma_{\mathrm{vo}}^{\prime}}}\right)$

\subsection{Liquid limit and plasticity index}

Liquid limit $w_{L}$ and plasticity index $I_{p}$ increase with an increase in the sleeve friction ratiowhile at the same time the tip resistance decreases [31, 40, 41]. According to Cetin and Ozan [31], liquid limit and plasticity index can be calculated using the following formulas:
$W_{\mathrm{L}}=10^{\left(1,506+0,310 \cdot \log F_{r}-\log q_{\mathrm{t}, 1, \text { net }} / 2,526\right)}$

$I_{\mathrm{P}}=10^{\left(1,058+0,592 \cdot \log F_{r}-\log q_{\mathrm{t}, 1, \text { net }} / 2,206\right)}$

where $q_{\mathrm{t}, 1, \text { net }}$ is the normalised net tip resistance calculated as follows:

$q_{\mathrm{t}, 1, \text { net }}=\frac{q_{\mathrm{t}}-\sigma_{\mathrm{vo}}}{\left(\frac{\sigma_{\mathrm{vo}}^{\prime}}{p_{\mathrm{a}}}\right)^{c}}$

where $c$ is the stress exponent dependent on the type of soil and stress level that can vary between 0.25 and 1 . It is calculated using the following formula:

$c=\frac{R-272,38}{275,19-272,38} 272,38<R<275,19$

Parameter $R$ in formula (16) is similar to the soil behaviour type index $I_{c}$ and is calculated using the formula:

$R=\sqrt{\left(\log q_{\mathrm{t}, 1, \text { net }}-233,52\right)^{2}+\left(\log F_{\mathrm{r}}+55,42\right)^{2}}$

If formula (16) is coupled with formulas (15) and (17) for calculating the stress exponent $c$, then we get:

$c=\frac{\sqrt{\left(\frac{q_{\mathrm{t}}-\sigma_{\mathrm{vo}}}{\left.\left(\frac{\sigma_{\mathrm{vo}}^{\prime}}{p_{\mathrm{a}}}\right)^{c}-233,52\right)^{2}+\left(\log F_{\mathrm{r}}+55,42\right)^{2}}-272,38\right.}}{275,19-272,38}$

Given that stress exponent c in formula (18) is located both on the right and left sides of the equation, the iteration procedure has to be applied for its calculation. For the first iteration, on the right hand side $c=1.0$ and the new $c$ value is calculated. This procedure is repeated until the difference in the values of the exponent $\Delta c$ is below or equal to 0.01 in two subsequent iterations.

\section{Application of CPT results in soil classification for the irrigation canal in Bid-Bosut Field}

Construction of the ameliorative irrigation canal in Bid-Bosut Field, $14772 \mathrm{~m}$ in length, is the first phase in the construction of the Danube-Sava multi-purpose canal. The excavation work for the canal has started at several locations in compliance with the existing detailed design. In the upper part, the design canal slope is 1:2. In its middle part, it becomes a wide berm, whereas in its lower part the slope amounts to 1:3. The average depth of the canal is approximately $7 \mathrm{~m}$. The excavation work was carried out using power shovels, which is a typical machine for this type of work (Figure 6) [13].

Foundation soil at the location of the canal consists of a thin surface layer of humus, providing cover to the layer of low-to-high plasticity clay, below which there are loose sands with different proportions of fine particles. Groundwater was discovered at the 


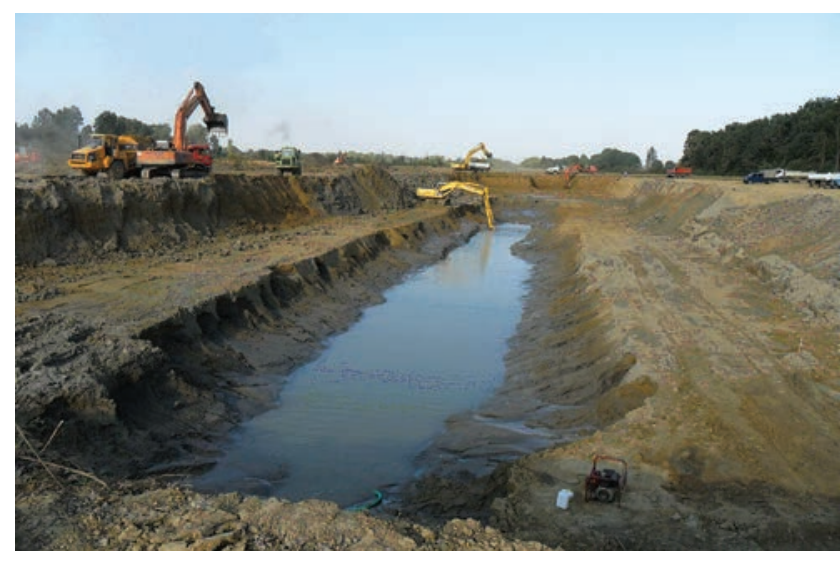

Figure 6. Canal excavation works [13]

depth of 4-5 m. Slope stability problems, and channel excavation and profiling difficulties, were caused in 2012 by low ground water levels experienced during excavation works at canal sections II and VI. Excavation under groundwater levels in sands and silty sands represented an additional problem to the builders.
During excavation under water, the soil would instantly turn into mud, and the slopes would erode. The work was interrupted in order to find a solution for proper excavation of the canal, such as construction of mild slopes under water, dry excavation involving drainage of water from the ground and construction pits, surface protection, etc. Given the evident fact that investigation works conducted for the detailed design purposes were not focused on resolving the problem of underwater excavation in loose and silty or clayey sands, the decision was made to conduct additional investigation works in order to gain better and more detailed insight into the foundational soil in the canal zone.

Additional geotechnical investigation works at the part of the route from $\mathrm{km} 0+600$ to $\mathrm{km} \mathrm{4+800} \mathrm{included:} \mathrm{fifteen} 12 \mathrm{~m}$ deep boreholes spaced at average intervals of $300 \mathrm{~m}$, with core classification, extraction of representative soil samples to be tested in laboratory and standard penetration tests (SPT) in the hole, trial pits 4-5 m deep at every $150 \mathrm{~m}$ along the considered canal route, together with soil classification and extraction of representative soil samples to be tested in the laboratory, cone penetration tests (CPT) for every hole together with two hold

Table 1. Results of the conducted CPT and laboratory classification tests

\begin{tabular}{|c|c|c|c|c|c|c|c|c|c|c|}
\hline GB/CPTU & RPV & Number & $\boldsymbol{z}[\mathrm{m}]$ & $\boldsymbol{q}_{\mathrm{t}}[\mathrm{MPa}]$ & $f_{\mathrm{s}}[\mathrm{kPa}]$ & $w_{\mathbf{L}}[\%]$ & $I_{\mathrm{p}}[\%]$ & $F C[\%]$ & $c_{u}$ & $c_{\mathrm{c}}$ \\
\hline \multirow{5}{*}{ GB-4/CPTU 4} & \multirow{5}{*}{4.70} & 1 & 2.30 & 1.34 & 126.10 & 45.32 & 21.23 & 67.95 & & \\
\hline & & 2 & 3.90 & 2.48 & 65.50 & 36.53 & 15.02 & 43.34 & & \\
\hline & & 3 & 5.20 & 1.90 & 36.80 & 31.15 & 13.95 & 54.88 & & \\
\hline & & 4 & 7.20 & 1.93 & 54.40 & 32.25 & 14.10 & 57.22 & & \\
\hline & & 5 & 11.00 & 23.07 & 79.60 & & & 4.56 & 2.94 & 1.44 \\
\hline \multirow{5}{*}{ GB-5/CPTU 5} & \multirow{5}{*}{5.00} & 6 & 2.30 & 0.91 & 102.00 & 47.86 & 29.20 & 62.07 & & \\
\hline & & 7 & 3.40 & 0.82 & 82.80 & 66.12 & 36.87 & 74.15 & & \\
\hline & & 8 & 4.70 & 1.35 & 14.50 & 32.15 & 14.25 & 39.22 & & \\
\hline & & 9 & 6.10 & 2.09 & 40.80 & 36.22 & 19.12 & 42.64 & & \\
\hline & & 10 & 10.50 & 19.00 & 82.00 & & & 4.02 & 5.00 & 1.80 \\
\hline \multirow{5}{*}{ GB-6/CPTU 6} & \multirow{5}{*}{5.60} & 11 & 2.00 & 1.05 & 92.00 & 53.25 & 29.93 & 65.22 & & \\
\hline & & 12 & 3.20 & 0.68 & 31.00 & 55.26 & 31.01 & 69.12 & & \\
\hline & & 13 & 6.10 & 0.82 & 15.00 & 47.44 & 25.81 & 65.07 & & \\
\hline & & 14 & 8.10 & 0.51 & 13.00 & 71.25 & 38.00 & 92.15 & & \\
\hline & & 15 & 10.20 & 10.19 & 18.00 & & & 3.25 & 4.65 & 2.12 \\
\hline \multirow{5}{*}{ GB-7/CPTU 7} & \multirow{5}{*}{5.30} & 16 & 3.70 & 1.17 & 82.00 & 44.12 & 32.57 & 67.22 & & \\
\hline & & 17 & 4.50 & 0.90 & 63.00 & 66.12 & 43.87 & 82.25 & & \\
\hline & & 18 & 6.40 & 1.09 & 55.20 & 53.42 & 29.79 & 61.52 & & \\
\hline & & 19 & 8.60 & 1.82 & 65.66 & 33.36 & 14.26 & 57.98 & & \\
\hline & & 20 & 10.30 & 14.27 & 20.00 & & & 4.38 & 1.92 & 1.17 \\
\hline \multirow{5}{*}{ GB-৪/CPTU 8} & \multirow{5}{*}{4.80} & 21 & 3.60 & 1.21 & 54.80 & 46.79 & 25.98 & 59.12 & & \\
\hline & & 22 & 4.60 & 1.20 & 37.00 & 38.91 & 16.16 & 62.18 & & \\
\hline & & 23 & 5.50 & 1.03 & 35.40 & 52.50 & 29.23 & 55.82 & & \\
\hline & & 24 & 6.80 & 0.98 & 13.20 & 35.10 & 13.26 & 51.17 & & \\
\hline & & 25 & 9.10 & 14.32 & 66.14 & & & 4.55 & 3.55 & 1.25 \\
\hline
\end{tabular}


tests for each hole, 15 piezometers with measuring points at approximately $8 \mathrm{~m}$ of depth for trial pumping conducted in drill holes, and laboratory testing for samples obtained from the holes (consistency levels, particle size distribution, direct shear). Layout of several drill holes (GB-4 to GB-8) and cone penetrations tests (CPTU 4 to CPTU 8) used in this paper are shown in Figure 7.

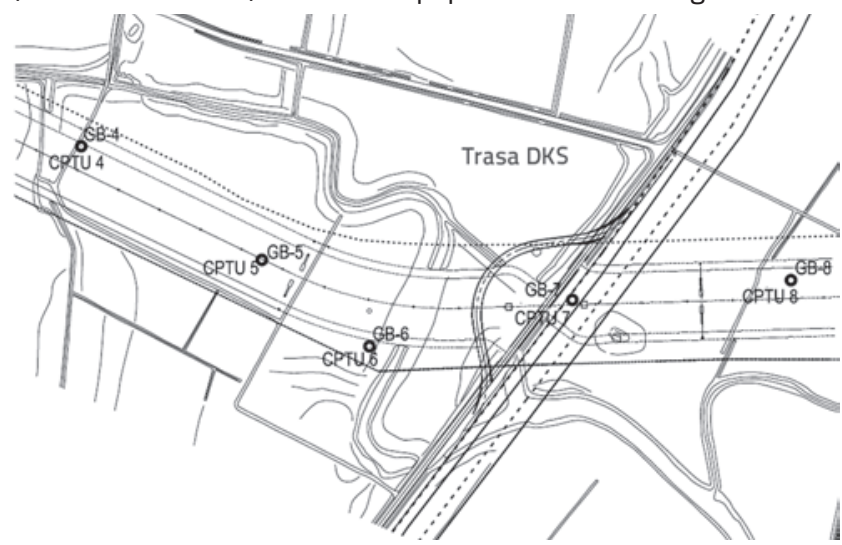

Figure 7. Positions of the relevant investigation works from $\mathrm{km}$ $1+450$ to $\mathrm{km} \mathrm{2+450}$
Table 1 shows cone penetration testing and laboratory classification testing results for samples taken at the same depths, which served to determine soil classification parameters using the shown statistic correlations. Tables 2 and 3 show comparative results of the USCS and ESCS soil classifications made using the CLASSIF program.

In Tables 2 and 3, the samples for which the application of CPT results and the shown correlation have led to a successful soil classification are marked in black, while the samples with unsuccessful classification are marked in red. It is evident that in both classifications there is a good percentage of successful soil classification attempts using the CPT results, despite the fact that the correlations were developed on different soils across the globe for which every author noted that they should be tested and corrected on local soil. This is due to the fact that, for soil classification, high accuracy of the forecast of classification parameters is not required, i.e. they should just be within a certain interval defined by a certain symbol, i.e. soil group name. Thus, for example, with USCS, it is important that the percentage of fine particles $(F C)$ is within the 6 possible intervals; $0 \%-5 \%, 5 \%-12 \%, 12 \%-50 \%, 50 \%-70 \%, 70 \%-85$

Table 2. Comparison of results of laboratory and CPT soil classification using the USCS classification

\begin{tabular}{|c|c|c|c|c|}
\hline \multirow{2}{*}{ Number } & \multicolumn{2}{|c|}{ USCS - laboratory } & \multicolumn{2}{|c|}{ USCS - CPT } \\
\hline & Symbol & Group name & Symbol & Group name \\
\hline 1 & $\mathrm{CL}$ & Sandy lean clay & $\mathrm{CL}$ & Sandy lean clay \\
\hline 2 & SC & Clayey sand & SC & Clayey sand \\
\hline 3 & $\mathrm{CL}$ & Sandy lean clay & $\mathrm{SC}$ & Clayey sand \\
\hline 4 & $\mathrm{CL}$ & Sandy lean clay & SC & Clayey sand \\
\hline 5 & SP & Poorly graded sand & SP & Poorly graded sand \\
\hline 6 & $\mathrm{CL}$ & Sandy lean clay & $\mathrm{CH}$ & Sandy fat clay \\
\hline 7 & $\mathrm{CH}$ & Fat clay with sand & $\mathrm{CH}$ & Fat clay with sand \\
\hline 8 & SC & Clayey sand & SC & Clayey sand \\
\hline 9 & SC & Clayey sand & SC & Clayey sand \\
\hline 10 & SP & Poorly graded sand & SP & Poorly graded sand \\
\hline 11 & $\mathrm{CH}$ & Sandy fat clay & $\mathrm{CL}$ & Sandy lean clay \\
\hline 12 & $\mathrm{CH}$ & Sandy fat clay & $\mathrm{CH}$ & Sandy fat clay \\
\hline 13 & $\mathrm{CL}$ & Sandy lean clay & $\mathrm{CL}$ & Sandy lean clay \\
\hline 14 & $\mathrm{CH}$ & Fat clay & $\mathrm{CH}$ & Fat clay \\
\hline 15 & SP & Poorly graded sand & $\mathrm{SP}$ & Poorly graded sand \\
\hline 16 & $\mathrm{CL}$ & Sandy lean clay & $\mathrm{CH}$ & Sandy fat clay \\
\hline 17 & $\mathrm{CH}$ & Fat clay with sand & $\mathrm{CH}$ & Fat clay with sand \\
\hline 18 & $\mathrm{CH}$ & Sandy fat clay & $\mathrm{CH}$ & Fat clay with sand \\
\hline 19 & $\mathrm{CL}$ & Sandy lean clay & $\mathrm{CL}$ & Sandy lean clay \\
\hline 20 & SP & Poorly graded sand & SP & Poorly graded sand \\
\hline 21 & $\mathrm{CL}$ & Sandy lean clay & $\mathrm{CL}$ & Sandy lean clay \\
\hline 22 & $\mathrm{CL}$ & Sandy lean clay & $\mathrm{CL}$ & Sandy lean clay \\
\hline 23 & $\mathrm{CL}$ & Sandy lean clay & $\mathrm{CL}$ & Sandy lean clay \\
\hline 24 & $\mathrm{CL}$ & Sandy lean clay & SC & Clayey sand \\
\hline 25 & SP & Poorly graded sand & $\mathrm{SP}$ & Poorly graded sand \\
\hline
\end{tabular}


Table 3. Comparison of results of laboratory and CPT soil classification using the ESCS classification

\begin{tabular}{|c|c|c|c|c|}
\hline \multirow{2}{*}{ Number } & \multicolumn{2}{|r|}{ ESCS - laboratory } & \multicolumn{2}{|r|}{ ESCS - CPT } \\
\hline & Symbol & Group name & Symbol & Group name \\
\hline 1 & saCll & Sandy clay of medium plasticity & saCll & Sandy clay of medium plasticity \\
\hline 2 & $\mathrm{clSa}$ & Clayey sand & $\mathrm{clSa}$ & Clayey sand \\
\hline 3 & saClL & Sandy clay of low plasticity & $\mathrm{clSa}$ & Clayey sand \\
\hline 4 & $\mathrm{saClL}$ & Sandy clay of low plasticity & $\mathrm{clSa}$ & Clayey sand \\
\hline 5 & GrP & Poorly graded sand & GrP & Poorly graded sand \\
\hline 6 & saCll & Sandy clay of medium plasticity & $\mathrm{saClH}$ & Sandy clay of high plasticity \\
\hline 7 & $\mathrm{saClH}$ & Sandy clay of high plasticity & $\mathrm{saClH}$ & Sandy clay of high plasticity \\
\hline 8 & $\mathrm{clSa}$ & Clayey sand & $\mathrm{clSa}$ & Clayey sand \\
\hline 9 & $\mathrm{clSa}$ & Clayey sand & $\mathrm{clSa}$ & Clayey sand \\
\hline 10 & GrP & Poorly graded sand & GrP & Poorly graded sand \\
\hline 11 & $\mathrm{saClH}$ & Sandy clay of high plasticity & $\mathrm{saCll}$ & Sandy clay of medium plasticity \\
\hline 12 & $\mathrm{saClH}$ & Sandy clay of high plasticity & $\mathrm{saClH}$ & Sandy clay of high plasticity \\
\hline 13 & saCll & Sandy clay of medium plasticity & $\mathrm{saCll}$ & Sandy clay of medium plasticity \\
\hline 14 & $\mathrm{ClH}$ & Clay of high plasticity & $\mathrm{ClH}$ & Clay of high plasticity \\
\hline 15 & GrP & Poorly graded sand & GrP & Poorly graded sand \\
\hline 16 & saCll & Sandy clay of medium plasticity & $\mathrm{SaClH}$ & Sandy clay of high plasticity \\
\hline 17 & $\mathrm{saClH}$ & Sandy clay of high plasticity & $\mathrm{SaClH}$ & Sandy clay of high plasticity \\
\hline 18 & $\mathrm{saClH}$ & Sandy clay of high plasticity & $\mathrm{saClH}$ & Sandy clay of high plasticity \\
\hline 19 & saCll & Sandy clay of medium plasticity & saCll & Sandy clay of medium plasticity \\
\hline 20 & GrP & Poorly graded sand & GrP & Poorly graded sand \\
\hline 21 & saCll & Sandy clay of medium plasticity & $\mathrm{saCll}$ & Sandy clay of medium plasticity \\
\hline 22 & saCll & Sandy clay of medium plasticity & saCll & Sandy clay of medium plasticity \\
\hline 23 & $\mathrm{saCll}$ & Sandy clay of medium plasticity & saCll & Sandy clay of medium plasticity \\
\hline 24 & saCll & Sandy clay of medium plasticity & $\mathrm{clSa}$ & Clayey sand \\
\hline 25 & GrP & Poorly graded sand & GrP & Poorly graded sand \\
\hline
\end{tabular}

$\%$ and $85 \%-100 \%$. With ESCS, there are 5 possible intervals: 0 $\%-5 \%, 5 \%-15 \%, 15 \%-50 \%, 50 \%-85 \%$ and $85 \%-100 \%$. For this reason, it would be more favourable for soil classification in statistic analyses, or through artificial intelligence, to classify the percentage of fine particles in relevant intervals, instead of determining their numerical value.

With USCS, the percentage of successful soil group assignment was $72 \%$, while with ESCS it was $76 \%$. The reason for this is sample No. 18, which, according to laboratory results, contains $38.08 \%$ of sand, and no more than $28.14 \%$ according to CPT results. According to USCS, the fine-grained soil that contains $30 \%$ or more of sand is described as "sandy" at the beginning of the group name, and fine-grained soil that contains between $15 \%$ and $30 \%$ of sand is described with the phrase "with sand" added at the end of the group name. Therefore, the result of the laboratory classification is "sandy fat clay", and the CPT classification result is "fat clay with sand". According to ESCS, fine-grained soil with $15 \%$ or more of sand is described as "sandy" at the beginning of the group name. Therefore, the result of both laboratory and CPT classifications is "sandy clay of high plasticity". The efficacy of determining soil symbols is the same for both classifications, although it is to be expected that for a larger number of samples the efficacy of ESCS will be higher. This is due to the fact that, with USCS, different soil group names can be attributed to the same symbol, whereas with ESCS, each symbol can indicate only one soil group name. For example, samples no. 14, 17 and 18 in USCS are all marked $\mathrm{CH}$, but have different soil group names: "fat clay", "fat clay with sand", and "sandy fat clay".

The relatively sound prognosis of soil classification according to USCS and ESCS presented in this paper via the example of the Bid-Bosut Field irrigation canal, using correlations shown in the paper, should nevertheless be taken with some reservations. A relatively small number of samples was used for comparison (25), which is not statistically relevant. The soil profile consisted of a small number of different materials: 16 samples of clay of varying plasticity with a significant content of sand, 5 samples of pure sand, 3 samples of clayey sand and only 1 sample of high plasticity clay. There were no samples of silty sand, nor samples of silt with varying content of sand. To enable the use of 
these correlations in practice, it would be necessary to conduct extensive research on a large number of samples containing a large number or almost all soil types referred to in USCS and ESCS.

\section{Conclusion}

Soil classification is usually carried out based on results of laboratory experiments conducted on disturbed samples of soil extracted from test drill holes. Samples are taken, on an average, for every 2 meters of depth, i.e. every time a layer changes, and this is the maximum resolution for describing and classifying soil. By applying the cone penetration test, soil data can be obtained for every $2 \mathrm{~cm}$ of depth, which ensures greater reliability of soil data. Soil classification using the cone penetration test results has been a great challenge in geotechnical engineering.

Four groups of parameters are used in soil classification. Direct and indirect correlations with CPT results have been developed for each of the parameters used in soil classification. The application of results obtained in the classification of soil at the Bid-Bosut Field irrigation canal has displayed a relatively successful use of shown correlations, although it should be noted that the number of samples and different soil types used were quite small. For soil classification in statistic analyses or through artificial intelligence, it is recommended to classify each parameter within the relevant interval, instead of determining their numerical value.

\section{REFERENCES}

[1] Casagrande, A.: Classification and identification of soils, Proc ASCE, 73 (1947) 6, pp. 783-810.

[2] ASTM D2487-11: Standard Practice for Classification of Soils for Engineering Purposes (Unified Soil Classification System). ASTM International, West Conshohocken, PA, 2011.

[3] Dumbleton, M.J.: The classification and description of soils for engineering purposes: a suggested revision of the British system, Ministry of Transport, RRL Report LR 182, Road Research Laboratory, Crowthorne, Berks. 1968.

[4] Dumbleton, M.J.: The British soil classification system for engineering purposes: its development and relation to other comparable systems, TRRL Report LR 1030, Transport and Road Research Laboratory, Crowthorne, Berks, 1981.

[5] BS 5930:1990: British Standard. Code of practice for site investigations. British Standards Institute, London, 1990.

[6] DIN 18196:2011-05: Erd- und Grundbau - Bodenklassifikation für bautechnishe Zwecke. Beuth Verlag GmbH, Berlin, 2011.

[7] Kovačević, M.S., Jurić-Kaćunić, D.: Europska klasifikacija tla za inženjerske potrebe, GRAEEVINAR, 66 (2014) 10, pp. 801-810.

[8] HRN EN ISO 14688-1:2008 en: Geotehničko istraživanje i ispitivanje - Identifikacija i klasifikacija tla - 1. dio: Identifikacija i opis. Zagreb, Hrvatski zavod za norme, 2008.

[9] HRN EN ISO 14688-1:2008/A1:2013 en: Geotehničko istraživanje i ispitivanje - Identifikacija i klasifikacija tla - 1. dio: Identifikacija i opis Amandman 1. Zagreb, Hrvatski zavod za norme, 2013.

[10] HRN EN ISO 14688-2:2008 en: Geotehničko istraživanje i ispitivanje - Identifikacija i klasifikacija tla - 2. dio: Načela klasifikacije. Zagreb, Hrvatski zavod za norme, 2008.

[11] HRN EN ISO 14688-2:2008/A1;2013 en: Geotehničko istraživanje i ispitivanje - Identifikacija i klasifikacija tla - 2. dio: Načela klasifikacije - Amandman 2. Zagreb, Hrvatski zavod za norme, 2013.

[12] Kovačević, M.S., Jurić-Kaćunić, D., Librić, L.: Prilagodba hrvatskog graditeljstva europskim smjernicama za opis i klasifikaciju tla, Izazovi u graditeljstvu 3, Lakušić, Stjepan (ur.). Zagreb: Hrvatski savez građevinskih inženjera, pp. 163-193, 2015.
[13] Marčić, D., Kovačević, M.S., Cvetković, M.: Ispitivanja koeficijenta propusnosti tla na kanalu za navodnjavanje Bid-Bosutskog polja, Dani gospodarenja vodama 2013, Napredak kroz znanost, Zagreb, pp. 171-200, 2013.

[14] Begemann, H.K.S.: The friction jacket cone as an aid in determining the soil profile, Proceedings of the $6^{\text {th }}$ International Conference on Soil Mechanics and Foundation Engineering, ICSMFE, Montreal, pp. 1720, 1965.

[15] Sanglerat, G., Nhim, T.V., Sejourne, M., Andina, R.: Direct soil classification by static penetrometer with special friction sleeve, Proceedings of the First European Symposium on Penetration Testing, ESOPT-1, pp. 337-344, 1974.

[16] Schmertmann, J.H.: Guidelines for cone test, performance, and design, Federal Highway Administration, Report FHWA-TS-78209, Washington, 1978.

[17] Douglas, B.J., Olsen, R.S.: Soil classification using electric cone penetrometer, American Society of Civil Engineers, ASCE, Proceedings of Conference on Cone Penetration Testing and Experience, St. Louis, pp. 209-227, 1981.

[18] Jones G.A., Rust, E.: Piezometer penetration testing, CPTU, Proceedings of the $2^{\text {nd }}$ European Symposium on Penetration Testing, ESOPT-2, Amsterdam, 2 (1982), pp. 607-614.

[19] Robertson, P.K., Campanella, R.G., Gillespie, D., Grieg, J.: Use of piezometer cone data, Proceedings of American Society of Civil Engineers, ASCE, Blacksburg, pp. 1263-1280, 1986.

[20] Robertson, P.K.: Soil classification using the cone penetration test, Canadian Geotechnical Journal, 27 (1990) 1, pp. 151-158, https:// doi.org/10.1139/t90-014

[21] Robertson, P.K.: Interpretation of cone penetration tests - a unified approach, Canadian Geotechnical Journal, 49 (2009) 11, pp. 1337-1355, https://doi.org/10.1139/T09-065

[22] Mayne, P.W.: Interpretation of geotechnical parameters from seismic piezocone tests. Proceedings, $3^{\text {rd }}$ International Symposium on Cone Penetration Testing, Las Vegas), pp. 47-73, 2014.

[23] ASTM D 422-63: Standard Test Method for Particle-Size Analysis of Soils, ASTM International, West Conshohocken, PA, 2007. 
[24] HRS CEN ISO/TS 17892-4:2008 en: Geotehničko istraživanje $i$ ispitivanje - Laboratorijsko ispitivanje tla - 4. dio: Određivanje granulometrijskog sastava, Zagreb, Hrvatski zavod za norme. 2008.

[25] ASTM D 4318-10: Standard Test Methods for Liquid Limit, Plastic Limit, and Plasticity Index of Soils, ASTM International, West Conshohocken, PA, 2010.

[26] HRS CEN ISO/TS 17892-12:2008 en: Geotehničko istraživanje $i$ ispitivanje - Laboratorijsko ispitivanje tla - 12. dio: Određivanje Atterbergovih granica, Zagreb, Hrvatski zavod za norme, 2008.

[27] Long, M.: Design parameters from in situ tests in soft ground - recent developments. Geotechnical and Geophisical Site Characterization, London, pp. 89-116, 2008, https://doi. org/10.1201/9780203883198.ch6

[28] Olsen, R.S., Mitchell, J.K.: CPT stress normalization and prediction of soil classification.Proc., Int. Symp. on Cone Penetration Testing, CPT 95, 2 (1995), pp. 257-262.

[29] Robertson, P.K., Wride, C.E.: Evaluating cyclic liquefaction potential using the cone penetration test, Canadian Geotechnical Journal, 35 (1998), pp. 442-459, https://doi.org/10.1139/t98-017

[30] Idriss, I.M., Boulanger, R.W.: Soil Liquefaction During Earthquake, Earthquake Engineering Research Institute, EERI Publication MNO-12, 2008.

[31] Cetin, K.O., Ozan, C.: CPT-Based Probabilistic Soil Characterization and Classification, Journal of Geotechnical and Geoenvironmental Engineering, 135 (2009) 1., pp. 84-107, https://doi.org/10.1061/ (ASCE) 1090-0241(2009)135:1(84)

[32] Yi, F.: Estimating soil fines contents from CPT data, Proc. $3^{\text {rd }}$ International Symposium on Cone Penetration Testing, Huntington Beach, Las Vegas, Nevada, USA, pp. 949-955, 2014.
[33] Pease, J.W: Case studies of CPT site specific correlation with normalized soil behavior type evaluation and fines content, Proc.

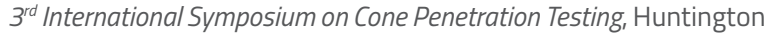
Beach, Las Vegas, pp. 573-582, 2014.

[34] Roy, S., Dass, G.: Statistical models for the prediction of shear strength parameters at Sirsa, India. International Journal of Civil \& Structural Engineering, 4 (2014) 4, pp. 483-498.

[35] Lun, A.C.Y.: Influence of grain size distribution on shear strength of sand, UG Thesis, Universiti Teknologi, Malaysia. 2011.

[36] Ahsan, Z., Chik, Z., Abedin, Z.: The Relationship Of Particle Gradation And Relative Density With Soil Shear Strength Parameters From Direct Shear Tests, Aust. J. Basic \& Appl. Sci., 8 (19), pp. 271-275. 2014.

[37] Kulhawy, F.H., Mayne, P.W.: Estimating Soil Properties for Foundation Design, EPRI Report EL-6800, Electric Power Research Institute, Palo Alto, 1990.

[38] Uzielli, M., Mayne, P.W., Cassidy, M.J.: Probabilistic assessment of design strengths for sands from in-situ testing data. Modern Geotechnical Design Codes of Practice, Advances in Soil Mechanics \& Geotech-nical Engineering (series), 1 (2013), pp. 214-227.

[39] Robertson, P.K., Campanella, R.G.: Interpretation of cone penetration tests - Part I (sand). Canadian Geotechnical Journal, 20 (1983) 4, pp. 718-733, https://doi.org/10.1139/t83-078

[40] Ozan, C.: Estimation of grain characteristics of soils by using CPT data. MS thesis, Middle East Technical Univ. 2003.

[41] Zein, A.K.M.: Use of cone penetration test for classification of local soils, BRR Journal, 5 (2003), pp. 23-29. 